\title{
MICHAŁ JASIŃSKI
}

Warsaw School of Economics, Poland

\section{Stages of Tourism Economy Penetration and the Phenomenon of Overtourism on Caribbean Islands}

\begin{abstract}
The purpose of the article is to determine the degree of tourism penetration on 30 island countries and dependencies of the Caribbean region. This tourism penetration is perceived as part of research in two dimensions: economic and socio-spatial. As a result of adopting such a perspective, stages of tourism penetration were determined using two indicators constructed for the research. The Tourism Economic Impact Index (TEI) measured the economic dimension, while the second indicator was the Tourist Socio-spatial Impact Index (TSI). Determining the degree of tourism penetration on these two dimensions was to identify those areas most exposed to economic threats resulting from 'tourism monoculture' (the final penetration phase of a tourism economy) and, as defined to discuss overtourism, the risks arising from too many inbound visitors at the same time. The research revealed that Caribbean dependent territories show the tendency to the highest penetration in both dimensions. Further analysis was made into the economic assessment of the phenomenon of 'tourism monoculture' and the dangers of this extreme form of export-oriented specialisation in the context of socio-economic development. Despite presenting positive premises, the phenomenon was critically assessed.
\end{abstract}

Keywords: Caribbean; overtourism; tourism monoculture

Received: 7 January 2020

Accepted: 29 April 2020

Suggested citation:

Jasiński, M. (2020). Stages of Tourism Economy Penetration and the Phenomenon of Overtourism on Carribbean Islands. Prace Komisji Geografii Przemysłu Polskiego Towarzystwa Geograficznego, 34(3), 150166. doi: $10.24917 / 20801653.343 .10$

\section{INTRODUCTION}

The dynamic development of tourism, mainly foreign, was characteristic of the later twentieth century and the first decades of the present one. Many countries and dependencies, in particular those underdeveloped, have seen in this phenomenon the opportunity for quickly overcoming socio-economic backwardness and ensuring sustainable development. This approach applies especially to groups of small islands located in the tropical zone. The growing demand for tourism on islands with warm seas and the 
opportunity to thus satisfy it raises several questions that are of research interest not only for economists (especially those dealing with development economics) but also for economic geographers. The research issue is about the boundaries and implications of the transformation of geographical space into an economic tourism space and the economy into a tourism monoculture and was the reason for the author to analyse the issue from these two perspectives. In a broader context, raising the theme of tourism monoculture is also an attempt to consider how to examine the issues of monoculture in an economy, and what tools to use to measure it.

As a result of these premises, the author attempted to answer three basic questions as the primary goal. First, should those Caribbean island economies that mainly offer tourist products for export be critically assessed? Secondly, are dependent territories or independent states more prone to reaching an extreme stage of tourism monoculture (penetration with tourism economy)? Thirdly, which of the analysed Caribbean islands seem to be the most exposed to the phenomenon of overtourism?

These questions determined the structure of the article which firstly outlines the phenomenon of development issues in the Caribbean and overtourism, paying particular attention to the specificity of small island economies and the importance of tourist product exports. Secondly, two indicators were constructed: the Tourism Economic Impact Index (TEI) and a Tourist Socio-spatial Impact Index (TSI). Thirdly, available data for 2015 and similar years (obtained from databases and publications of the World Bank and the World Tourism Organization) for 30 Caribbean nations and territories were applied to these indicators, obtaining (partly) their values. These values enabled the separation of three stages of penetration for the tourism product economy and tourism. The article then consolidates available knowledge about tourism monoculture using TEI and TSI. The final part summarises the analyses and presents conclusions.

\section{LITERATURE REVIEW}

Numerous conflicts caused by overtourism in recent years, e.g. in Amsterdam, Barcelona, Dubrovnik, Majorca, Santorini and Venice, have caused a wave of interest in the negative aspects of the development of modern tourism (including Briguglio, Avellino, 2019; Jasiński, 2019b; Kowalczyk-Anioł, 2015; Kowalczyk-Anioł, Włodarczyk, 2017; Kowalczyk-Anioł, Zmyślony, 2017; Seraphin, Sheeran, Pilato, 2018; Stanchev, 2018). Conflicts caused by overtourism and the local population were analysed earlier through many concepts. Those most commonly accepted in the specialist literature include the idea of changing the attitudes of permanent residents towards tourism - the so-called Doxey index (the Irridex, the Irritation Index) (Doxey, 1975, 1976), the Tourism Area Life Cycle (TALC) (Butler, 1980), and the concept of tourism carrying capacity.

The Caribbean region was one of the first areas where, as early as in the 1960s and 1970s, specialists pointed not only to social and ecological problems but also to economic ones. The latter resulted from a too intensive development of reception tourism (e.g. Bryden, 1973; Giezgała, 1969, 1977; Hałaciński, 1970, 1972; Kadt, 1979; Zacziniajew, Falkowicz, 1975). From the economic perspective, in this period the most significant threat was considered to be 'crossing the border of tourism specialisation' and thus causing 'dependence' on the revenues from tourist product exports (Giezgała, 
1969, 1977; Hałaciński, 1970, 1972). This phenomenon was described as 'tourist monoculture'1.

Economic tourism specialisation, to varying degrees, remains characteristic of the Caribbean islands. However, in a changing global economy with the free flow of goods and services, and with a high level of liberalisation of international trade, it is difficult to describe this as 'an extension of the colonial system' (Hałaciński, 1970, Kadt, 1979). It is also challenging to maintain the thesis that the development of the tourism economy was 'pushed' by, for instance, the U.S., which saw 'tourism specialisation' in this region as a 'disruption' of the development processes leading to the 'economic dependence' of these areas (Giezgała, 1969, 1977; Zacziniajew, Falkowicz, 1975). However, such a narrative is still often adopted in the literature when assessing the economic effects of tourism development. However, the accelerating development evoked by this form of economic activity and the achievement of a high socio-economic level for some areas of the region ( $c f$. Table 1 and Jasiński, 2017, 2018, 2019a) questions its justification.

The Caribbean is an incredibly diverse area in cultural, social, political and economic terms. As a result, this concept of 'the Caribbean' has many meanings. It can be assumed that the Caribbean is composed of insular communities, English-speaking, Spanish-speaking, Francophone, Dutch, American, etc. The Caribbean can be spoken of in terms of the African, Caribbean and Pacific (ACP) Working Party², Caribbean Economic Community (CARICOM) ${ }^{3}$, the Greater Caribbean (which in addition to the islands, also includes coastal states), or the Caribbean Sea Basin (Gawrycki, 2004, Komosa, 2006, Lara, 2006).

${ }^{1}$ According to the Polish literature, the term 'tourist monoculture' refers to economies (countries and territories) whose nature has been dominated (subordinated) by tourist activities (tourism economy) aimed mainly at servicing foreign inbound tourist traffic (see Giezgała, 1969, 1977; Hałaciński, 1970, 1972; Jasiński, 2006, 2008a, 2008b; Kachniewska, Nawrocka, Niezgoda, Pawlicz, 2012; Wodejko, 1998). In English literature, in turn, the same concept of SITE (McElroy, 2006, 2010) has been adopted - which is an acronym for the words: small, island, tourist economies. The latter term seems to be more precise because the phenomenon of 'tourist monoculture' (from a macroeconomic point of view) occurs primarily in small island geopolitical units. An exception to the rule can be cited (with high probability) only Caribbean Belize, which is indeed a little but not the insular state. The contractual value, when the economy becomes 'dependent' on tourist product exports (i.e. a 'tourist monoculture'), was over $20 \%$ of revenues from tourist product exports in GDP in the 1980 s, and $25 \%$ in the 1990s (Wodejko, 1989, 1998). The issues of 'tourist monoculture' in Polish literature on the subject in recent years have also been raised by J. Kowalczyk-Anioł (Kowalczyk-Anioł, 2017) and B. Wójtowicz (Wójtowicz, 2019).

2 The ACP Working Group deals with the cooperation of the European Union (EU) with these countries under the Cotonou Agreement signed in 2000. It is the most comprehensive partnership agreement concluded by the EU with developing countries of the Global South. It refers to the EU's relations with 79 countries, including 16 in the Caribbean: Antigua and Barbuda, Bahamas, Barbados, Belize, Dominica, Dominican Republic, Grenada, Guyana, Haiti, Jamaica, Cuba, St. Kitts and Nevis, St. Lucia, St. Vincent and the Grenadines, Suriname and Trinidad and Tobago. The Cotonou Agreement sets the framework for development and trade, as well as the principles of political cooperation. Its main goal is to eliminate poverty in ACP countries (Council of the European Union, 2019).

${ }^{3}$ As of 2019, CARICOM consisted of 15 full members (Antigua and Barbuda, Bahamas, Barbados, Belize, Dominica, Grenada, Guyana, Haiti, Jamaica, Montserrat, St. Kitts and Nevis, St. Lucia, St. Vincent and the Grenadines, Suriname and Trinidad and Tobago), five associate members (Anguilla, Bermuda, British Virgin Islands, Cayman Islands and Turks and Caicos Islands) and eight observers (Aruba, Curaçao, Dominican Republic, Colombia, Mexico, Puerto Rico, the Dutch part of Sint Maarten and Venezuela) (CARICOM, Caribbean Community, 2019).

4 The area understood in this way, for reasons of geostrategic security of the USA, has been treated as an American direct zone of influence. As a result, Washington, for example, allows the possibility of military intervention in this region. During the Cold War, the term was widely used in both the USA and the Soviet Union. The area understood in this way includes both island states, Central America, Belize and Guyana, as well as Colombia, Mexico and Venezuela. After the end of the East-West conflict, the concept of the Caribbean 
The insularity of the majority of countries and dependencies in this area ${ }^{5}$, as well as their 'tourist economic specialisation', prompted the World Tourism Organization (UNWTO) to narrow the Caribbean to this group only. Other (continental) nations were classified with the rest of the subregions of the Americas, including the Central subregion of Belize, Guatemala, Honduras, Costa Rica, Nicaragua, Panama and El Salvador (UNWTO, 2017).

This last perspective prompted the author to analyse the development issues of the Caribbean through the prism of the so-called 'geographical school's. From this point of view, the majority of Caribbean islands can be considered as Small Island Developing States (SIDS). They constitute a specific group ${ }^{7}$ which is characterised by vulnerability resulting from geographical features such as small size, limited natural resources, isolation and instances of natural disasters. These features determine their narrow economic specialisation and marginal importance in international trade. Their economies are not able to take advantage of economies of scale and are dependent on imports. They show a low level of the use of labour resources; the cultural dominance of the 'North'; high costs of transportation, infrastructure and administration; and susceptibility to criminal activities (e.g. money laundering, drugs, corruption). The limited opportunities for SIDS economic specialisation mean that in the majority of cases, the development of international tourism (export of tourist products) seems to be the only possibility of overcoming socio-economic stagnation (Jasiński, 2017).

Another equally important issue in the context of development conditions for the Caribbean is to pay attention to two elements. First of all, the existence of relatively large nations such as Cuba, the Dominican Republic and Haiti (see Table 1). These countries are usually not classified as SIDS because they have, theoretically, more favourable conditions for development - tourism is not their sole export ${ }^{8}$. Secondly, due to a large number of dependent territories whose formal and legal status is different to an independent state, development opportunities are significantly affected. Some of these territories should be considered as parts of a broader economic entity. According to

Sea Basin began to be identified with small countries, particularly sensitive to the effects of economic globalisation (Komosa, 2006).

${ }^{5}$ It is estimated that at the beginning of the 21 st century the total number of Caribbean islands (at least $1 \mathrm{~km} 2$ ) was 3.7 thousand, of which only 1.6 thousand were named. Their area totalled 234 thousand $\mathrm{km} 2$, of which $89 \%$ was occupied by the Greater Antilles (Cuba, Hispaniola, Jamaica, Puerto Rico), 6\% by the Bahamas and the remaining $5 \%$ by the Lesser Antilles. According to the data at the time, the total population of this area was 42 million (Higman, 2011). It is currently estimated at 44 million (World Bank, 2019).

${ }^{6}$ Cf. (Garbicz, 2012; Jasiński, 2019a; Rodrik, 2002).

${ }^{7}$ According to the "unofficial" list of the United Nations Conference on Trade and Development (UNCTAD), 28 independent countries are considered SIDS: 12 located in Oceania (Federated States of Micronesia, Fiji, Kiribati, Nauru, Palau, Samoa, Timor-Leste, Tuvalu, Vanuatu, Marshall Islands, Solomon Islands and Tonga Islands); 10 in the Caribbean (Antigua and Barbuda, Bahamas, Barbados, Dominica, Grenada, Jamaica, Saint Kitts and Nevis, Saint Lucia, Saint Vincent and the Grenadines and Trinidad and Tobago); two located in the Eastern Atlantic (Cape Verde and São Tomé and Príncipe) and four in the Indian Ocean (Maldives, Mauritius, Seychelles and Union of Comoros) (UNCTAD, 2019).

${ }^{8}$ In 1972, UNCTAD introduced the term Island Developing Countries (IDC), widely accepted in the literature. Initially, it included "large" islands, such as Madagascar, Sri Lanka, Indonesia and the Philippines. This later became the reason for its modification. The IDC issues undertaken by UNCTAD overlapped with the research trend, growing since the 1980s, on the development of "small" countries. As a result, in 1994 UNCTAD decided to narrow down its area of interest to SIDS. Modifying the scope of research and changing the name did not, however, dispel several doubts. Among them is the fact that to this day, UNCTAD alone has not been able to create a complete, unquestionable list of small island developing economies (Jasiński, 2020). Hence, for the article, the author considers SIDS not only small (independent) island states (cf. footnote 7), but also dependent territories. 
many researchers, the socio-economic development of small island states, and especially island dependent territories, is directly proportional to the strength of the political connections of these areas with former and present colonial powers. In other words, the greater the relationship, the higher the level of development (Armstrong, De Kervenoael, Li, Read, 1998; Armstrong, Read, 2000; Bertram, 2004; Bertram, Poirine, 2018; McElroy, Sanborn, 2005). Some researchers are inclined to the thesis that this is one of the essential elements reducing the pursuit of independence in the still numerous dependent islands globally ${ }^{9}$.

\section{RESEARCH METHODS}

To more fully demonstrate the economic significance of the tourist product export for the 30 Caribbean nations and territories analysed (Table 1), modified ${ }^{10}$ indicators were used: Tourism Economic Impact Index (TEI) and Tourist Socio-spatial Impact Index (TSI).

The construction of the first index is based on three approaches to the economic significance of incoming foreign tourism for each of the analysed (x) countries and dependencies. The first is the total revenues from the export of the tourist product, calculated per capita. The second is the total revenues from tourist product exports compared to the volume of revenues from all foreign economic exchange (to revenues from the export of goods and services). The third is a statement of revenue from the export of the tourist product to the entire economy measured by gross domestic product.

The formula (min-max) was applied for the three measures, obtaining three indicators, which can be written as:

$$
\begin{aligned}
& \text { TPE per capita } \mathrm{x}=\left(\mathrm{X}-\mathrm{X}_{\min }\right):\left(\mathrm{X}_{\max }-\mathrm{X}_{\min }\right) \\
& \text { TPE/EGS }=\left(X-X_{\text {min }}\right):\left(X_{\text {max }}-X_{\text {min }}\right) \\
& \text { TPE } / G P_{x}=\left(X-X_{\text {min }}\right):\left(X_{\text {max }}-X_{\text {min }}\right)
\end{aligned}
$$

where:

TPE/GDP - tourist product export (USD),

TPE per capita - tourist product export per capita (USD),

TPE/EGS - tourist product export divided by the export of goods and services (percentage),

TPE/GDP - tourist product export divided by the gross domestic product (percentage), $\mathrm{X}$ - the value of the indicator for a given state,

$X_{\max }$ - the highest value of the indicator for a given state,

$\mathrm{X}_{\min }$ - the lowest value of the indicator for a given state.

The three TPE per capita indicators, TPE/EGS and TPE/GDP indices for a given ( $\mathrm{x}$ ) nation/territory were then indexed (normalising the obtained values) according to the formula:

\footnotetext{
${ }^{9}$ Palau (1994) in Oceania and East Timor (2002) became the last of the SIDS to gain independence.

${ }^{10}$ Compare the indicators used by the author in: (Jasiński, 2019a, 2019b).
} 


$$
T E I x=\frac{(T P E \text { per capitax }+T P E / E G S x+T P E / G D P x)}{3}
$$

making it possible to obtain a synthetic index (TEI) for a particular (x) state. The tourist product export index in the economy can range from 0 to 1 . Higher TEI values mean a more substantial penetration of the economy with tourism.

Besides these, the TSI index was used given the limited area of the Caribbean islands. Its method of construction was analogous to the TEI including four elements describing the human use of space (islands) and the impact of visitors (tourists and sameday visitors) on the local population: (1) the ratio of the number of foreign tourists to the number of permanent residents; (2) the number of tourists per $\mathrm{km}^{2}$; (3) the ratio of the number of same-day visitors to the number of permanent residents; and (4) the number of one-day visitors per $\mathrm{km}^{2}$.

The formula (min-max) was used for the four measures, obtaining four indicators, which can be written as:

$$
\begin{aligned}
& \mathrm{NT} / \mathrm{NPR}_{\mathrm{x}}=\left(\mathrm{X}-\mathrm{X}_{\text {min }}\right):\left(\mathrm{X}_{\text {max }}-\mathrm{X}_{\text {min }}\right) \\
& \mathrm{NT} / \mathrm{km}_{\mathrm{x}}^{2}=\left(\mathrm{X}-\mathrm{X}_{\text {min }}\right):\left(\mathrm{X}_{\text {max }}-\mathrm{X}_{\text {min }}\right) \\
& \mathrm{NE} / \mathrm{NPR}_{\mathrm{x}}=\left(\mathrm{X}-\mathrm{X}_{\text {min }}\right):\left(\mathrm{X}_{\text {max }}-\mathrm{X}_{\text {min }}\right) \\
& \mathrm{NE} / \mathrm{km}_{\mathrm{x}}^{2}=\left(\mathrm{X}-\mathrm{X}_{\text {min }}\right):\left(\mathrm{X}_{\text {max }}-\mathrm{X}_{\text {min }}\right)
\end{aligned}
$$

where:

NT - the number of foreign tourists,

NT/NPR - the ratio of the number of foreign tourists to the number of permanent residents (percentage),

$\mathrm{NT} / \mathrm{km}^{2}$ - the number of tourists per $\mathrm{km}^{2}$,

NE/NPR - the ratio of the number of same-day visitors ('excursionists') to the number of permanent residents (percentage),

$\mathrm{NE} / \mathrm{km}^{2}$ - the number of one-day visitors per $\mathrm{km}^{2}$,

$\mathrm{X}$ - the value of the indicator for a given state,

$\mathrm{X}_{\max }$ - the highest value of the indicator for a given state,

$\mathrm{X}_{\min }$ - the lowest value of the indicator for a given state.

The obtained four indicators: NT/NPR, NT $/ \mathrm{km}^{2}$, NE/NPR and NE $/ \mathrm{km}^{2}$ for a particular $(\mathrm{x})$ state, were then indexed according to the formula:

$$
\text { WSPNRTx }=\frac{(N T / L S M x+N T / k m 2 x+L O J / L S M x+L O J / k m 2 x)}{4}
$$

making it possible to obtain the TSI for a particular (x) nation/territory. Similar to the TEI, the indicator of socio-spatial tourism penetration can have values from 0 to 1 . A higher value of the TSI means substantial socio-spatial penetration. 


\section{RESEARCH RESULTS}

Applying the available data from 2015 (or similar years) ${ }^{11}$ contained in Tables 1 and 2 resulted in obtaining TEI values for 16 island groups (Table 2). The highest indicators (above 0.400) were for Aruba, Anguilla, U.S. Virgin Islands, Bahamas, Antigua and Barbuda. Average indicators (between 0.399 and 0.200) were for Lucia, Dominica, Grenada, Curaçao, Barbados, Jamaica, St. Kitts and Nevis, St. Vincent and the Grenadines, and Bermuda. The lowest (below 0.199) were for the Dominican Republic and Trinidad and Tobago.

In some other areas, only partial indicators were obtained. Based on their analysis (Table 2), it can be concluded that in some of the states, the tourist product export plays a dominant role in the development process. Dependent territories should be mentioned as examples: Sint Maarten (Dutch), Saint-Martin (French), British Virgin Islands and the Cayman Islands.

When considering the volume of tourist product exports for a given Caribbean island economy, its socio-spatial constraints should be taken into account. Using the TSI as an additional tool in TEI analysis, it should be stated that the highest socio-spatial indicator in 2015 (out of the 25 islands where it could be calculated - Table 3) was on the Dutch Sint Maarten and amounted to a maximum value of 1,000. In this case, all the TSI partial indicators confirmed the most substantial tourism pressure among the islands analysed. The number of foreign tourists in 2015 amounted to nearly 15 times the number of permanent residents. In the case of same-day visitors - cruise passengers - their number accounted for almost 56 times the inhabitants - which may seem in the case of such a small area $\left(34 \mathrm{~km}^{2}\right)$ especially conflict-causing (overtourism). There are clear analogies to the situation in Venice.

High TSI values (above 0.300) in 2015 were also obtained in the British Virgin Islands, Aruba, and Turks and Caicos. Averages (between 0.299 and 0.100) in the Cayman Islands, U.S. Virgin Islands, Bermuda, St. Kitts and Nevis, Bahamas and Anguilla. In the cases of Antigua and Barbuda, Curaçao, Barbados, St. Lucia, Grenada, Dominica, Martinique, Guadeloupe, Puerto Rico, St. Vincent and Grenadine, Jamaica, Dominican Republic, Trinidad and Tobago, Cuba and Haiti, the TSI values were low (below 0.099) (Table 3).

\section{DISCUSSION}

The facts which determined the decision to choose the 'tourist development path', especially in the case of SIDS, include minimal natural resources, political and historical conditions, such as the consequences of the 'sugar plantation economy' and the specific political and economic systems functioning after 1945 (including in the Dominican Republic, Haiti, and $\mathrm{Cuba}$ ). Others are social conditions, the nature of relationships with former colonisers, and especially a favourable location concerning a large market for

\footnotetext{
${ }^{11}$ Despite the seemingly easy access and obtaining statistical data, it should be borne in mind that a significant part of the information on the Caribbean area is questionable and burdened with errors. Moreover, in some cases, significant discrepancies between them are visible. This is particularly the case of dependent territories. In many cases, there is a lack of data, which prompted the author to refer later in the article (Discussion) to the conclusions of his own and other earlier studies and not directly to the source statistical materials.
} 


\begin{tabular}{|c|c|c|c|c|c|c|c|c|c|c|c|c|c|c|c|c|c|c|c|c|c|c|c|c|c|c|c|c|c|c|}
\hline 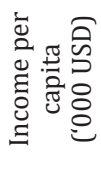 & 1 & 1 & $\begin{array}{l}\tilde{O} \\
\delta \\
\tilde{\sigma} \\
\tilde{N}\end{array}$ & $\begin{array}{l}n \\
\hat{n} \\
\text { ñ }\end{array}$ & $\begin{array}{l}\text { ת } \\
\text { ת } \\
\text { N } \\
\end{array}$ & $\begin{array}{l}\text { No } \\
\text { of } \\
\text { + }\end{array}$ & 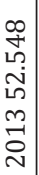 & 1 & 1 & 1 & $\begin{array}{l}0 \\
\text { o } \\
0 \\
0 \\
0\end{array}$ & $\begin{array}{l}0 \\
\sim \\
\\
\sim \\
\sim\end{array}$ & 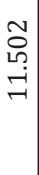 & 1 & ה & $\begin{array}{l}0 \\
\text { ำ } \\
m \\
\infty\end{array}$ & $\begin{array}{c}m \\
\infty \\
\infty \\
N\end{array}$ & $\begin{array}{l}\text { ᄂ } \\
\text { 염 } \\
\end{array}$ & 1 & 1 & $\begin{array}{c}0 \\
m \\
\\
m\end{array}$ & 1 & 1 & I & 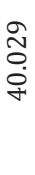 & $\begin{array}{l}v \\
m \\
\sim \\
\sim \\
N\end{array}$ & مَ & $\begin{array}{r}N \\
\tilde{n} \\
\tilde{n}\end{array}$ & $\begin{array}{l}\sigma \\
\stackrel{+}{+} \\
0 \\
\infty \\
\sim\end{array}$ & $\begin{array}{c}m \\
\sigma \\
\sim \\
\tilde{r} \\
\sim\end{array}$ \\
\hline 焉 & 1 & 1 & $\begin{array}{l}0 \\
\infty \\
\tilde{N} \\
0\end{array}$ & I & $\stackrel{N}{\tilde{\sigma}}$ & مٌ & 1 & 1 & 1 & 1 & $\stackrel{0}{N}$ & $\stackrel{N}{N}$ & 官 & 1 & $\begin{array}{l}m \\
\text { gे } \\
\dot{0}\end{array}$ & 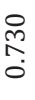 & 1 & $\begin{array}{c}\text { N } \\
\hat{\sigma}\end{array}$ & 1 & 1 & 1 & 1 & 1 & 1 & 1 & $\begin{array}{l}\text { ص } \\
\text { مै }\end{array}$ & $\begin{array}{l}n \\
\tilde{n} \\
\tilde{0}\end{array}$ & $\stackrel{N}{\tilde{N}}$ & $\begin{array}{l}0 \\
\infty \\
\\
0\end{array}$ & I \\
\hline
\end{tabular}

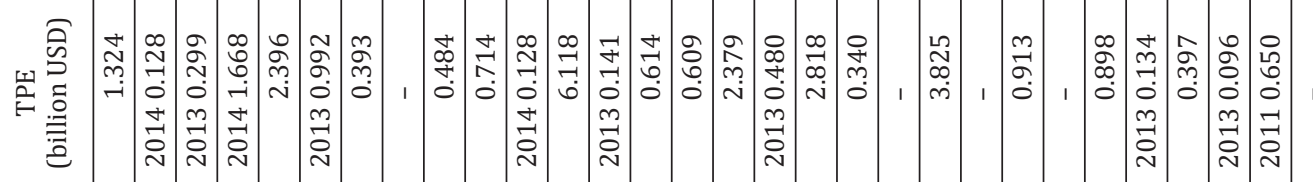

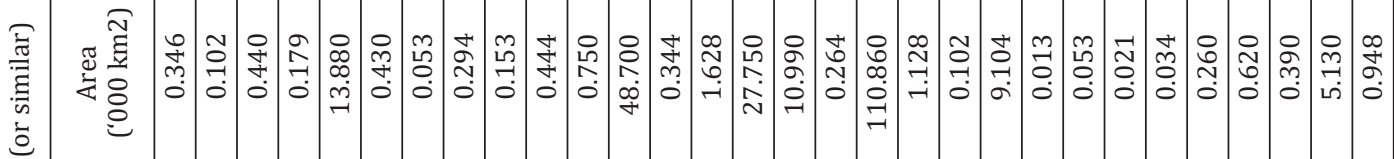

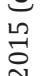

$\Xi$

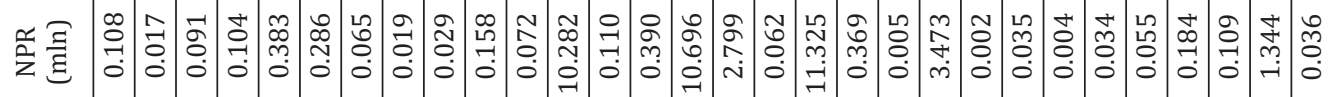

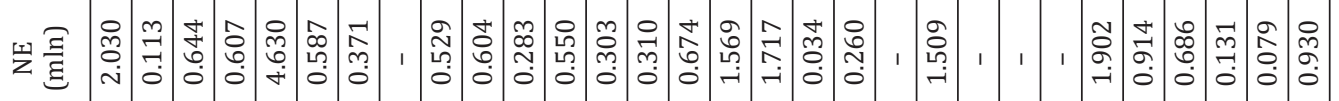

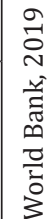

$\frac{\pi}{\sqrt{2}}$

ฐี

है

பั

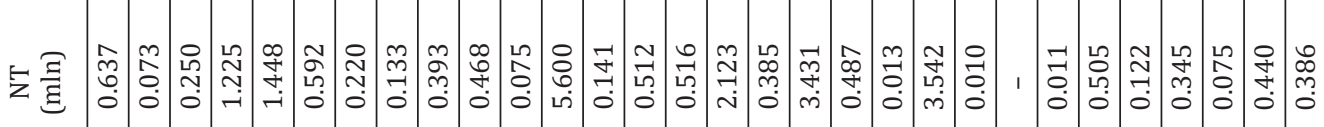

논

:

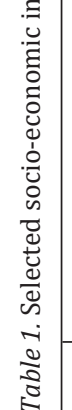

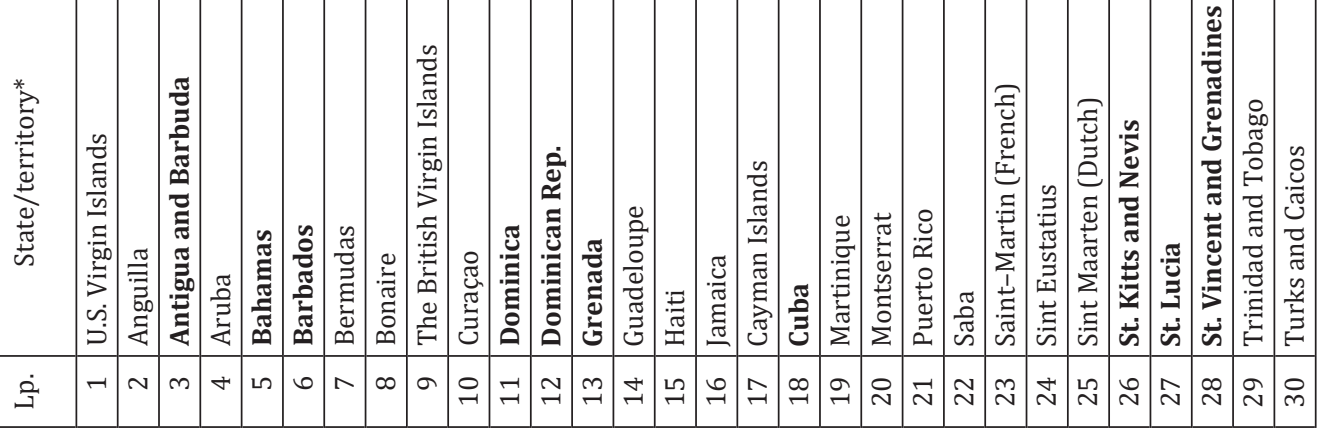




\begin{tabular}{|c|c|c|c|c|c|c|c|c|c|c|c|c|c|c|c|}
\hline 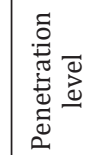 & $\stackrel{\breve{b 0}}{.00}$ & 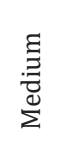 & ${ }_{3}^{3}$ & 1 & I & ' & ' & 1 & 1 & 1 & & 1 & 1 & 1 & 1 \\
\hline
\end{tabular}

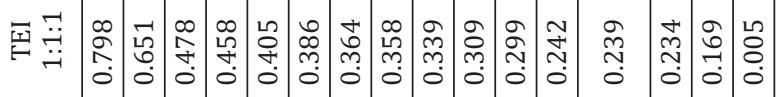

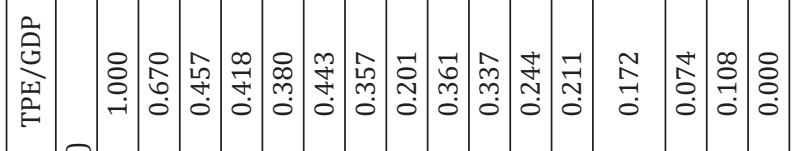

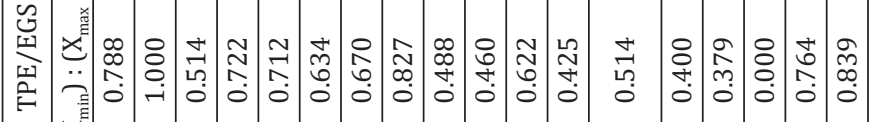

空

$$
\begin{aligned}
& \text { 풀 }
\end{aligned}
$$

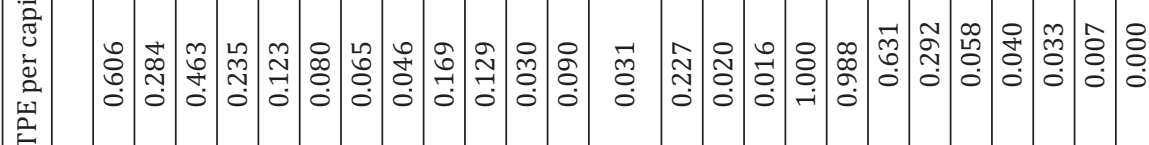
矛全

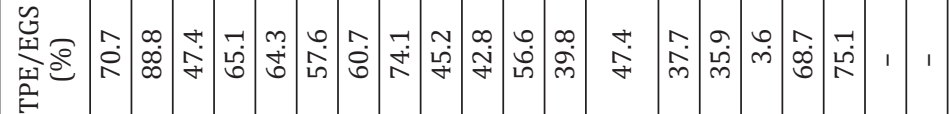

ᄒํ.

폴

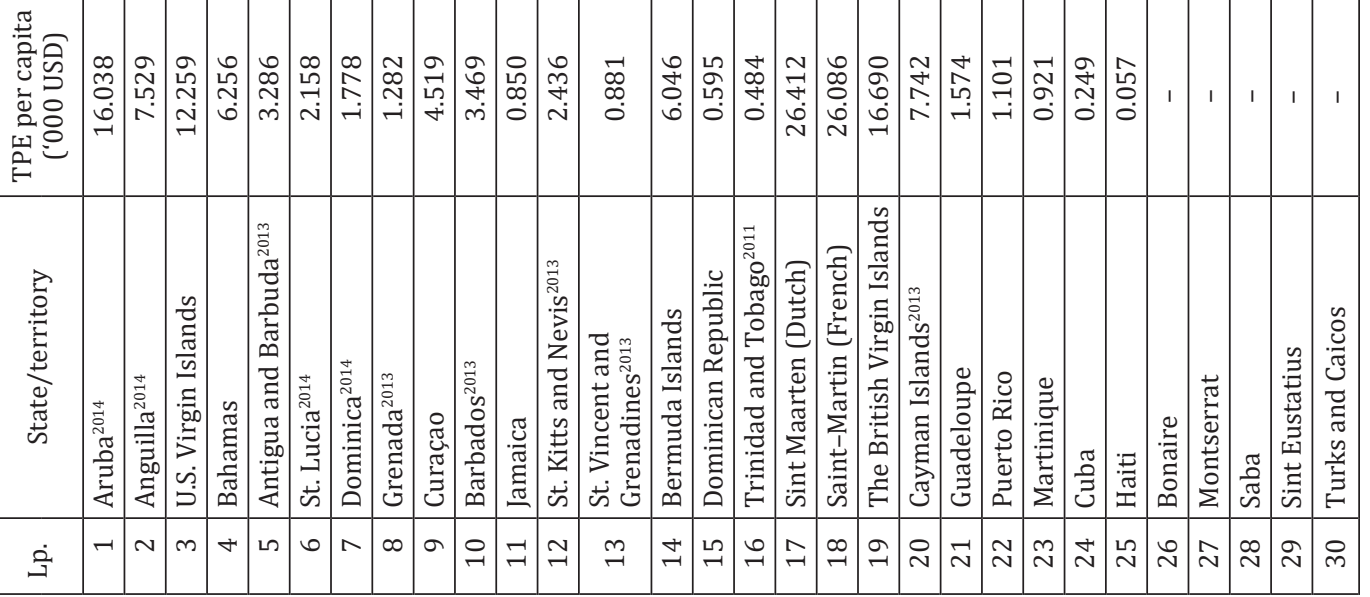




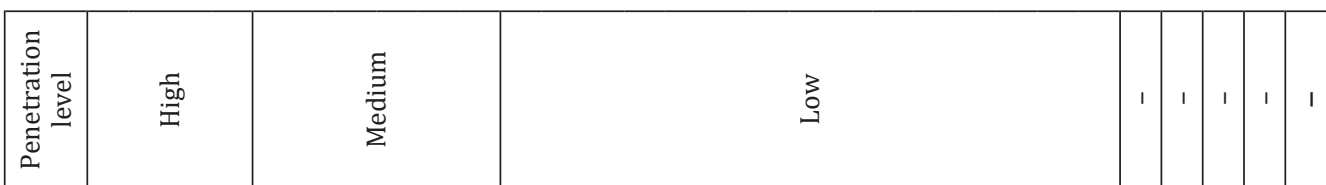

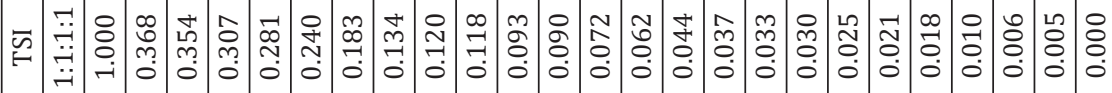

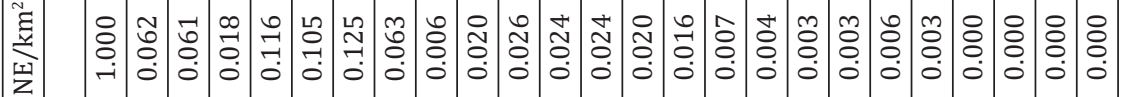

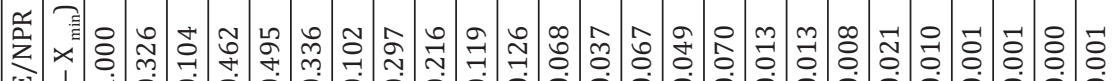

罗

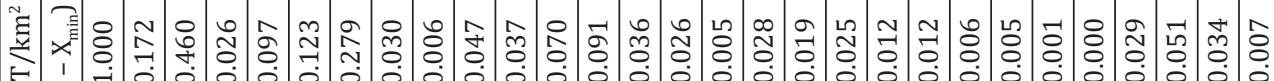

范

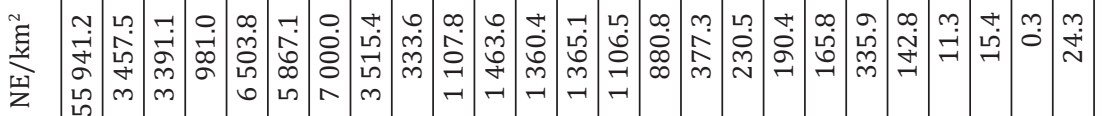

穵

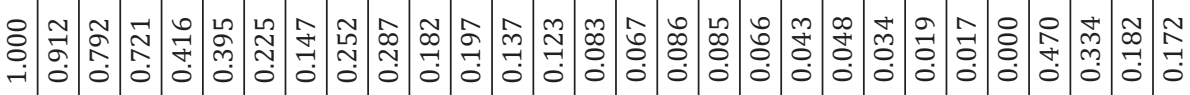

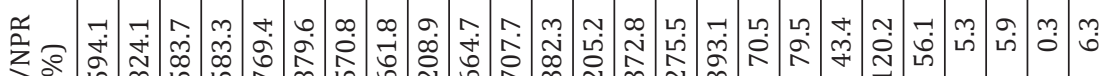

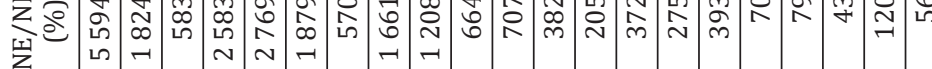

こ

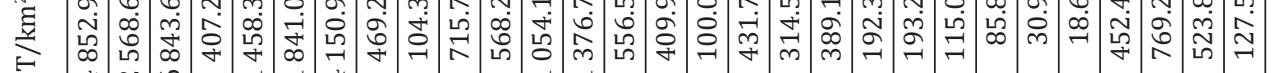

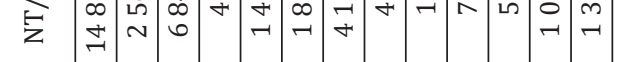

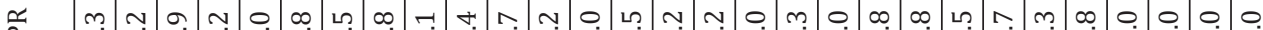

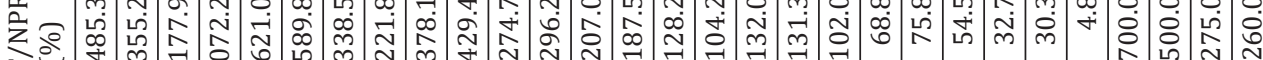

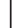

임

क

紊

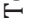

$\stackrel{\Xi}{E}$

$\frac{8}{8}$

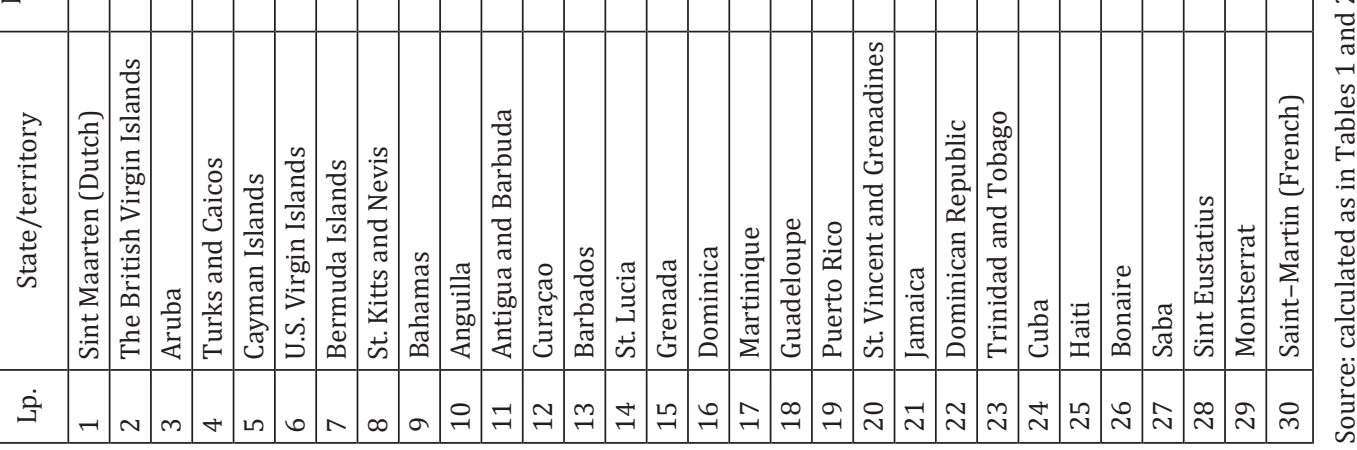


international tourists (Canada, the United States of America) (cf, among other things: Jędrusik, 2005; Higman, 2011; Landes, 2007; Lara, 2006; Ratter, 2018).

The consequences of deciding to conduct and continue an economic policy based on maximising income from tourist product exports can be looked at, taking into account this broad context. If we want to narrow this scope, it is possible to include only three issues: (1) the period in which the economic orientation began to change towards tourism and, as a result, how long the tourism economy has been operating; (2) with what intensity the tourism economy has supplanted other forms of economy - i.e. how it is penetrated with tourism; and (3) how the entire economy is managed ('control over it', including particularly skilful incorporation of the tourism economy into all economic processes) (cf. Jasiński, 2017, 2018).

In the first case, there is a clear tendency that the earlier the phase of intensive integration into the global tourism economy (from the 1950s to 1970s), the higher the level of development and the longer-lasting socio-economic effects. The confirmation is found in the examples from dependent territories (cf. Bertram, Poirine, 2018), but also some independent nations. This issue primarily refers to SIDS such as Antigua and Barbuda, Bahamas, and Barbados (Jasiński, 2017, 2018, 2019a), and - more arguably - the relatively large Dominican Republic (see Table 1). However, in the case of some of the analysed Caribbean islands, the principle according to which 'catching up' nations, that is those that began to conduct economic policy based on the pursuit of maximisation of income from exporting tourist products at a later date, such as Cuba ${ }^{12}$, are developing more dynamically. They are not as spectacular, though, as SIDS such as Maldives and Palau (Jasiński, 2017, 2018, 2019a). The socio-economic success, especially of the Bahamas and Barbados, also shows how important a role the other two issues play, i.e. with what intensity the tourism economy has supplanted other forms and how the entire economy is managed.

When considering the supplanting of other forms of economic activity by tourism, the dangers arising from the extreme form of 'Dutch Disease' (Rybczynski, 1955; The Economist, 1977; Corden, Neary, 1982; Corden, 1984; Budnikowski, 2017), as well as the degree of penetration of the whole economy must be taken into account. Based on a conventional indicator TPE/GDP (Table 2), commonly used in the literature to diagnose tourism monoculture, it should be stated that in nine cases there are reasons to confirm it (TPE/GDP above 20\% - see footnote 1, Jasiński, 2008a). In Aruba (TPE/GDP of $61.0 \%$ ), the monoculture can be considered advanced, and in Anguilla (TPE/GDP of $41.8 \%$ ) average. In the remaining seven states/territories (U.S. Virgin Islands, St. Lucia, Bahamas, Antigua and Barbuda, Curaçao, Dominica and Barbados) the economies are to a lesser extent based on monocultural tourism (TPE/GDP from $22.4 \%$ to $29.4 \%$ ).

${ }^{12}$ Cuba is a specific example of a country that has entered the "tourist development path" for the second time. The first period, until 1959, focused mainly on the tourist product export to the USA. After the change of political and economic orientation in 1960, this specialisation was intensively limited. As a result of financial problems, in 1995 renewed gradual involvement in the world tourism economy began, again directing the main streams of tourist product exports to the USA (Jasiński, 2008b). Nowadays, tourism in Cuba is becoming more and more important for the economic development of this country, and it stands out in those terms in the region. In 2015 Cuba recorded 3.431 million foreign tourists and USD 2.818 billion in revenues from tourism. This has an impact on the current level of social and social development economic (cf. Table 1). For instance, in 1990-1994, the HDI index in Cuba showed a downward trend (in individual years it was, respectively, 0.676; 0.670; 0.663; 0.656; 0.652). However, from 1995 to 2018, its upward trend is clear (for subsequent years, respectively: $0.665 ; 0.669 ; 0.672 ; 0.679 ; 0.686 ; 0.692 ; 0.693 ; 0.704 ; 0.718 ; 0.730 ; 0.752 ; 0.768$; $0.778 ; 0.780 ; 0.776 ; 0.775 ; 0.764 ; 0.762 ; 0.764 ; 0.768 ; 0.771 ; 0.777 ; 0.778$ ) (UNDP, 2019). Therefore, it can be assumed that the "second" phase of joining the global tourism economy has contributed to the dynamic acceleration of development processes in this country. 
Despite the lack of complete data (see Table 2), additional indicators, such as TPE per capita or ET/EGS (Table 2), show that Sint Maarten and Saint-Martin should also be classified as economies strongly dominated by tourist specialisation (extreme tourism monocultures). Referring additionally to the TEI and TSI results obtained (Tables 2 \& 3), it can be claimed that dependent territories have a greater tendency to reach a final stage of tourism monoculture, i.e. penetration with tourism. This phenomenon can be explained by the fact that these areas do not have to actively strive to strengthen resilience to political blackmail, economic pressure, military threats, threats of blockades or supply embargoes, as is the case with independent nations. Security understood in such a way is guaranteed by the colonial power. On the other hand, relatively large nations, the Dominican Republic, Cuba, or even the smaller Trinidad and Tobago (see Tables 2 \& 3), are less likely to achieve advanced monoculture as these have a broader range of development opportunities. In the case of Haiti (slightly penetrated with tourism - Tables 2 \& 3), the unstable economic and political situation should be considered the most significant obstacle to development, both to tourist specialisation and general development processes.

Let us return to the topic of diagnosing the degree of tourism monoculture based on the TPE/GDP ratio, accepting this reasoning. It should be stated that in the cited cases of the Bahamas and Barbados, the importance of tourist product exports for development processes either has a decreasing tendency in the long term or is relatively proportionally constant. At the initial stage of development of a tourist economy, e.g. in the Bahamas, the TPE/GDP ratio remained at a very high level (one of the highest in the world). In the following years, it gradually decreased. In 1980 it was $89.0 \%$, then it dropped to $52.1 \%$ (1985), 45.0\% (1990), 40.8\% (1995), and reached $35.3 \%$ in 2000 (Jasiński, 2006, 2008a). In 2015, it stood at 27.1\% (Table 2). In the case of Barbados, in turn, tourism monoculture has never been strong. From the beginning, the TPE/ GDP ratio was at a relatively consistent level. In 1980 it was $31.1 \%$, followed by $26.2 \%$ (1985), 29.1\% (1990), 38.7\% (1995), 33.2\% (2000) (Jasiński, 2006, 2008a). In 2015 it stood at $22.4 \%$ (Table 2). Growing revenues from tourism in both nations from the TPE, along with an increasing GDP and a decreasing TPE/GDP ratio has meant a reduction in the degree of 'monoculturalism' in this sector.

From this perspective, the decreasing or stabilisation of the TPE/GDP ratio in these two nations can be considered a desirable and economically beneficial effect of the conditions that characterise these SIDS. It can also be said that the Bahamas and Barbados 'control' their economies, i.e. they skillfully integrate tourism into all economic processes. The most important thing when conducting this type of policy is the use of a significant part of tourism revenues to finance other direct investments (e.g. agriculture, infrastructure, energy, education, health protection, environmental protection, and the like), and not only imports of consumer goods (see Bożyk, 2004). Confirmation of this beneficial mechanism includes high development rates (see Table 1) and, what seems most important, a stable economic and political situation of both. The latter, together with a relatively liberal legal system, has enabled the expansion of activities with financial services (tax havens) and thus a specific diversification of the economy after a final tourism-based phase (Jasiński, 2017, 2018).

Trying to assess the export-oriented tourism specialisation in the Caribbean from a contemporary perspective, it can be stated that the success of tourism monocultures, especially in areas strongly affected by them, will last as long as their tourist product is 
attractive. In this approach, taking into account, of course, unfavourable mechanisms resulting from the 'Dutch Disease', the possibility of a sudden, mass outflow of tourists must be taken into account. This phenomenon may be due to a variety of reasons, including political, ecological, health, terrorist threats or the phenomenon of overtourism, and would mean an economic catastrophe for these areas.

Referring to the simplified, three-phase TALC model, based on the results of the TEI and TSI, it should be stated that economies with a high degree of tourism penetration are in the mature TALC phase. These are the economies most exposed to the phenomenon of overtourism. Aruba and Sint Maarten are particularly special cases. For these territories, the decrease in the number of consumers of the tourist product (high TSI) may cause the most significant economic disturbances (high TEI). Similar conclusions (also based on previous research results - cf. among other things, McElroy, 2006) can also be applied to other dependent territories (including Anguilla, the American and British Virgin Islands, Saint-Martin and Turks and Caicos) and nations (Antigua and Barbuda and the Bahamas). For some of these areas, TEI and TSI are not high. They are therefore not in a situation of both extreme tourism monoculture and the phase of exceeding tourist absorption capacity. However, they must be particularly sensitive to the dangers of overtourism as a consequence of tourism monoculture.

The use of tourist product export indicators in the economy (TEI) and the socio-spatial penetration of tourism (TSI) may be an additional tool indicating the approach of Caribbean islands both to the limit of tourist absorption and the limit of tourism penetration.

To conclude, it should be stated that the contemporary assessment of the phenomenon of the extreme tourist export specialisation of Caribbean islands is complicated and, despite the positive premises presented, rather critical (Garbicz, 2012; Jasiński, 2019a). Economic security is the most persuasive argument and difficult to challenge. The Caribbean islands, like any nations "which are very one-sided and run a monocultural economy, are exposed to various shocks coming from the outside world to a much greater extent than if their economy was more diversified" (Garbicz, 2012: 68). One can also agree with the further argument of Garbicz that "they have no escape or rescue strategy due to the underdevelopment of other sectors. Their economy is dislocated, one-sided, and therefore excessively sensitive and not resistant to external blows" (Garbicz, 2012: 69). In the case of the Caribbean, however, there can be significant doubt. Can small island nations and territories, due to their conditions, be compared to large or even medium economies and be seen from the perspective of a single measure? In the author's opinion, this dislocation is inscribed in the specificity of the Caribbean economies. As economic history shows, monoculturalism has been a characteristic of most island areas of the region for several centuries (see Jędrusik, 2005; Higman, 2011; Landes, 2007; Lara, 2006; Ratter, 2018), which of course does not change the fact that they remain in a situation without an escape strategy.

The presented discussion and doubts lead to the conclusion that the economic assessment of tourism monoculture on the Caribbean islands should be approached with great caution and with insight, taking into account primarily the development conditions of these economies, as well as the geopolitical system of the region. It should also be borne in mind that the export of tourist products is a specific form of economic activity. To some extent, it is difficult to compare it to a specialisation in the export of natural resources such as oil or natural gas, etc., and most often the 'Dutch Disease' is referred 
to in these monocultures. When exporting a tourist product, the buyers must come from abroad. This fact, in turn, can create negative social and ecological phenomena, especially at a large scale of tourism. As a consequence, it can incur several economic costs not mentioned in this article which should also be taken into account in a comprehensive assessment of tourism monoculture. They, in turn, will further intensify the difficulties of taking a clear position on the issue of extreme export-oriented tourist specialisation of the Caribbean region.

\section{CONCLUSIONS}

Based on the TEI values obtained, as well as partial indicators and measures, for the 30 island nations and territories of the Caribbean region, it was found that on the U.S. Virgin Islands, Anguilla, Antigua and Barbuda, Aruba, Bahamas, British Virgin Islands, Cayman Islands, Saint-Martin and Sint Maarten, tourist product exports play a particularly significant role in development processes. These economies are highly penetrated with a tourism specialisation. On St. Lucia, Dominica, Grenada, Curaçao, Barbados, Jamaica, St. Kitts and Nevis, St. Vincent and the Grenadines, Bermudas, Guadeloupe and Puerto Rico, this level was considered medium. However, in the case of the Dominican Republic, Trinidad and Tobago and Martinique, Cuba and Haiti, it was low. In other areas, based on indicators and measures other than those used directly in the research, and on other source materials, the economies of Turks and Caicos can be considered highly penetrated with tourism, while Bonaire, Montserrat, Saba and Sint Eustatius are medium.

Further analysis, based on TSI, as well as indicators, sub-measures and other source materials, has made it possible to state that the territories of Sint Maarteen and Saint-Martin, the British Virgin Islands, Aruba and Turks and Caicos are the most penetrated with tourism. As a result, in these areas, the most significant consequences of overtourism are found. In other parts, including the Cayman Islands, U.S. Virgin Islands, Bermuda, St. Kitts and Nevis, Bahamas and Anguilla, penetration was medium. In contrast, low penetration was recorded in the remaining areas (Antigua and Barbuda, Curaçao, Barbados, St. Lucia, Grenada, Dominica, Martinique, Guadeloupe, Puerto Rico, St. Vincent and the Grenadines, Jamaica, Dominican Republic, Trinidad and Tobago, Cuba and Haiti). In the cases of Bonaire, Saba, Sint Eustatius of the island of Montserrat (based on random data), an average penetration was assumed.

The obtained values (despite their incompleteness), additionally based on an analysis of the literature on the subject, enabled to address the issue of the consequences of tourism monoculture and prospects for further development for the economies of the Caribbean islands characterised by this phenomenon. In particular, the following three research questions were answered.

In the case of the first of them, it was stated that despite presenting positive premises, from a contemporary perspective, extreme tourism export specialisation should be assessed critically. The lack of economic security resulting from tourism monoculture was considered the most persuasive argument in favour of such an assessment. In the second case, dependent territories were recognised as areas showing a greater tendency to extreme penetration with tourism and achieving the most advanced pro-export tourism specialisation. The island of Sint Maarten/Saint Martin was primarily recognised as such an extreme form. These territories, including the British Virgin Islands, Aruba as well as Turks and Caicos, were considered the most threatened by the 
possibility of overtourism. These areas, due to the intensive development of tourism, must take into account the risk of tourist overpenetration, which in their cases entails consequent economic dangers.

In conclusion, the indicators Tourism Economic Impact Index (TEI) and Tourist Socio-spatial Impact Index (TSI) may be synthetic, simple tools for measuring the degree of tourism penetration of small island economies and the high values achieved are a warning signal. However, the author is aware that their simplicity may discourage some from agreeing, and because of this, TEI and TSI are susceptible to criticism.

\section{REFERENCES}

Armstrong, H.W., De Kervenoael, R.J., Li, X., Read, R. (1998). Comparison of the Economic Performance of Different Micro-states, and Between Micro-states and Larger Nations. World Development, 26(4), 639-656.

Armstrong, H.W., Read, R. (2000). Comparing the Economic Performance of Dependent Territories and Sovereign Microstates. Chicago: University of Chicago, 285-306.

Bertram, G., Poirine B. (2018). Economics and Development. W: G. Baldacchino (red.) The Routledge International Handbook of Island Studies. A World of Islands. New York: Routledge.

Bertram, G. (2004). On the Convergence of Small Island Economies with Their Metropolitan Patrons. World Development, 32(2), 343-364.

Bożyk, P. (2004). Zagraniczna i międzynarodowa polityka ekonomiczna. Warszawa: Polskie Wydawnictwo Ekonomiczne.

Briguglio, L., Avellino, M. (2019). Has overtourism reached the Maltese islands? Occasional Papers on Islands and Small States, 1, 1-27.

Bryden, J.M. (1973). Tourism and Development. A Case Research of the Commonwealth Caribbean. Cambridge: Cambridge University Press.

Budnikowski, A. (2017). Ekonomia międzynarodowa. Warszawa: Polskie Wydawnictwo Ekonomiczne.

Butler, R.W. (1980). The concept of a tourist area cycle of evolution: implications for management of resources. Canadian Geographer, 24(1), 5-12.

CARICOM, Caribbean Community. (2019). Available: https://caricom.org/

Corden, W.M. (1984). Booming Sector and Dutch Disease Economics: Survey and Consolidation. Oxford Economic Papers, 36(3), 359-380.

Corden, W.M., Neary, J.P. (1982). Booming Sector and De-industrialization in a Small Open Economy. Economic Journal, 92, 825-848.

Council of European Union (2019). Available: https://www.consilium.europa.eu/pl/council-eu/ preparatory-bodies/african-caribbean-pacific-working-party/

Doxey, G.V. (1975). A causation theory of visitor/resident irritants: Methodology and research inferences. Proceedings of the Travel Research Association 6th Annual Conference. San Diego: Travel Research Association, 195-198.

Doxey, G.V. (1976). When enough's enough: The natives are restless in Old Niagara. Heritage Canada, 2, 26-28.

Garbicz, M. (2012). Problemy rozwoju i zacofania ekonomicznego. Dlaczego jedne kraje sq biedne, podczas gdy inne sq bogate? Warszawa: Oficyna a Wolters Kluwer business.

Gawrycki, M.F. (2004). Unia Europejska - Ameryka Łacińska i Karaiby. Trudne partnerstwo dwóch regionów. Warszawa: Oficyna Wydawnicza ASPRA-JR.

Giezgała, J. (1969, 1977). Turystyka w gospodarce narodowej. Warszawa: Polskie Wydawnictwo Ekonomiczne.

Hałaciński, P. (1970). Turystyka a międzynarodowy obrót ekonomiczny. Ekonomista, 5, 923-942.

Hałaciński, P. (1972). Ekonomiczne problemy współczesnej turystyki międzynarodowej. Warszawa: Szkoła Główna Planowania i Statystyki (Ruch Turystyczny-Monografie, 11).

Higman, B.W. (2011). A Concise History of the Caribbean. Cambridge: Cambridge University Press. Human Development Report. (2016). New York: United Nations Development Program. 
Jasiński, M. (2006). Aspekty monokulturowe gospodarki turystycznej. Zeszyty Naukowe Kolegium Gospodarki Swiatowej, 20, 92-102.

Jasiński, M. (2008a). Turystyka a małe gospodarki wyspiarskie. Zeszyty Naukowe Kolegium Gospodarki Światowej, 23, 195-218.

Jasiński, M. (2008b). Zrównoważony rozwój w monokulturowych gospodarkach turystycznych. W: S. Wodejko (ed.), Zrównoważony rozwój turystyki. Warszawa: Oficyna Wydawnicza Szkoła Główna Handlowa w Warszawie.

Jasiński, M. (2017). Modele rozwoju gospodarczego a poziom rozwoju społecznego i zamożności w małych państwach wyspiarskich na świecie. Studia i Prace, Wydział Nauk Ekonomicznych i Zarzq̨dzania Uniwersytetu Szczecińskiego, 49(2), 317-333.

Jasiński, M. (2018). Nasycenie gospodarki turystyką a poziom rozwoju społeczno-ekonomicznego w małych rozwijających się państwach wyspiarskich. Prace Komisji Geografii Przemysłu Polskiego Towarzystwa Geograficznego, 32(2), 311-324.

Jasiński, M. (2019a). Turystyka i pomoc rozwojowa a poziom rozwoju społeczno-ekonomicznego w państwach Południa o niekorzystnym położeniu geograficznym oraz najsłabiej rozwiniętych. Prace Komisji Geografii Przemysłu Polskiego Towarzystwa Geograficznego, 33(3), 127-147.

Jasiński, M. (2019b). The Impact of International Tourism on the EU Small States. Occasional Papers on Islands and Small States, 3, 1-7.

Jasiński, M. (2020). Podwójna izolacja jako determinanta rozwoju społeczno-ekonomicznego małych państw wyspiarskich Globalnego Południa (in print).

Jędrusik, M. (2005). Wyspy tropikalne. W poszukiwaniu dobrobytu. Warszawa: Wydawnictwo Uniwersytetu Warszawskiego.

Kachniewska, M., Nawrocka, A., Niezgoda, A., Pawlicz, A. (2012). Rynek turystyczny. Ekonomiczne zagadnienia turystyki. Warszawa: Oficyna a Wolters Kluwer business.

Kadt, E. (ed.). (1979). Tourism - Passport to Development?: Perspectives on the Social and Cultural Effects of Tourism in Developing Nations. Oxford: Oxford University Press.

Komosa, M. (2006). Polityka zagraniczna państw karaibskich. In: M.F. Gawrycki (ed.). Polityka zagraniczna państw Ameryki Łacińskiej. Warszawa: Wydawnictwa Uniwersytetu Warszawskiego.

Kowalczyk-Anioł, J. (2015). Syndrom wenecki. Dysfunkcje współczesnej turystyki w miastach cennych kulturowo. In: M. Durydiwka, K. Duda-Gromada (edo.). Przestrzeń $w$ turystyce. Znaczenie i wykorzystanie. Warszawa: Uniwersytet Warszawski, Wydział Geografii i Studiów Regionalnych.

Kowalczyk-Anioł, J. (2017). Społeczno-ekonomiczne dysfunkcje rozwoju monokultury turystycznej na wschodnim wybrzeżu meksykańskiego Jukatanu. Ekonomiczne Problemy Turystyki, 1, 209-222.

Kowalczyk-Anioł, J., Włodarczyk, B. (2017). Przestrzeń turystyczna przestrzenią konfliktu. Prace i Studia Geograficzne, 62(2), 53-72.

Kowalczyk-Anioł, J., Zmyślony, P. (2017). Turystyka miejska jako źródło protestów społecznych: przykłady Wenecji i Barcelony. Turystyka Kulturowa, 2, 7-36.

Landes, D.S. (2007). Bogactwo i nędza narodów. Dlaczego jedni sq tak bogaci, a inni tak ubodzy. Warszawa: Warszawskie Wydawnictwo Literackie MUZA SA.

Lara, O.D. (2006). Space and history in the Caribbean. Princeton: Markus Wiener Publishers.

McElroy, J. L. (2006). Small island tourist economies across the life cycle. Asia Pacific Viewpoint, 47(1), 61-77.

McElroy, J.L., Parry, C.E. (2010). The characteristics of small island tourist economics. Tourism and Hospitality, 10, 315-328.

McElroy, J.L., Sanborn, K. (2005). The Propensity for Dependence in Small Caribbean and Pacific Islands. Bank of Valletta Review, 31, 1-16.

Ratter BMW (2018). Geography of Small Islands. Outposts of Globalization. Switzerland: Springer International Publishing AG.

Rodrik, D. (2002). Institutions, Integration, and Geography: In Search of the Deep Determinants of Economic Growth. Available: https://wcfia.harvard.edu/publications/ institutions-integration-and-geography-search-deep-determinants-economic-growth. 
Rybczynski, T.M. (1955). Factor Endowment and Relative Commodity Prices, Economica, New Series, 22, 336-341.

Seraphin, H., Sheeran, P., Pilato, M. (2018). Over-tourism and the fall of Venice as a destination. Journal of Destination Marketing \& Management, 9, 374-376.

Stanchev, R. (2018). The most affected European destinations by over-tourism. Palma: University of the Balearic Islands.

The Economist (1977). 26 November, 82-83.

UNCTAD (2019). Available: https://unctad.org/

UNDP (2019). Available: http://hdr.undp.org/en/data\#

UNWTO. (2017). Compendium of Tourism Statistics, Data 2011-2015. Madrid: UNWTO.

Wodejko S. (1989). Ruch przyjazdowy z zachodu do wybranych państw socjalistycznych jako wyraz luki na europejskim rynku turystycznym. Warszawa: Szkoła Główna Planowania i Statystyki, Monografie i Opracowania, 288.

Wodejko, S. (1998). Ekonomiczne zagadnienia turystyki. Warszawa: Wyższa Szkoła Handlu i Prawa.

World Bank (2019). Available: https://data.worldbank.org/

Wójtowicz, B. (2019). Ruch turystyczny a poziom rozwoju społeczno-ekonomicznego Mauritiusa. Prace Komisji Geografii Przemysłu Polskiego Towarzystwa Geograficznego, 33(3), 100-111.

Zacziniajew, P.N., Falkowicz, N.S. (1975). Geografia turystyki międzynarodowej. Warszawa: Państwowe Wydawnictwo Naukowe.

Michal Jasinski, PhD Econ., Jean Monnet Chair of the European Union, Collegium of Socio-Economics, Warsaw School of Economics. His academic interests include socio-economic processes of development in the Global South, especially in Small Island Developing States (SIDS) and International Tourism and Official Development Assistance (ODA) in those processes.

ORCID: 0000-0002-0546-5048

\section{Address:}

Szkoła Główna Handlowa w Warszawie Katedra Unii Europejskiej im. J. Monneta al. Niepodległości 162, 02-554 Warszawa, Polska e-mail: michal.jasinski@sgh.waw.pl 